\title{
Analisis Faktor Pemilihan Jajanan, Kontribusi Gizi dan Status Gizi Siswa Sekolah Dasar
}

\author{
Factors Analysis of Snack Choice, Nutrition Contribution and Nutritional \\ Status of Primary School Children
}

\author{
Dwikani Oklita Anggiruling, Ikeu Ekayanti, Ali Khomsan \\ Departemen Gizi Masyarakat, Fakultas Ekologi Manusia, Institut Pertanian Bogor \\ (dwikani.oklita@gmail.com)
}

\begin{abstract}
ABSTRAK
Pemenuhan kebutuhan gizi anak penting dilakukan untuk mendukung proses pertumbuhan dan perkembangan. Pola makan anak usia sekolah yang cenderung lebih memilih jajan di sekolah dibandingkan makan di rumah akan mempengaruhi status gizi anak. Tujuan dari penelitian ini adalah menganalisis faktor-faktor yang mempengaruhi pemilihan jajanan, hubungan pemilihan jajanan dengan frekuensi jajan serta hubungan kontribusi jajan dengan status gizi anak sekolah. Penelitian ini merupakan penelitian cross-sectional yang didanai oleh Neysvan Hoogstraten Foundation, the Netherlands dan dilakukan di tiga SD yaitu SDN Kedokan, SD Pajajaran dan SDN Cibogo Kecamatan Cisauk, Kabupaten Tangerang dengan total subjek penelitian berjumlah 109 siswa. Analisis faktor dan uji hubungan Rank Spearman digunakan untuk menganalisis data. Terdapat lima faktor utama yang menjadi determinan pemilihan jajanan yaitu faktor familiaritas, karakteristik jajanan, lingkungan dan sosial, kandungan gizi dan variasi serta kesehatan. Faktor kesehatan dan karakteristik jajanan memiliki hubungan yang signifikan dengan frekuensi jajan $(\mathrm{p}<0.05)$. Kontribusi energi, protein, lemak dan karbohidrat memiliki hubungan yang nyata dengan status gizi anak $(\mathrm{p}<0.05)$. Hasil penelitian menunjukkan bahwa pemilihan jajanan berperan penting pada kebiasaan jajan anak dan kontribusi gizi jajanan berdampak pada status gizi anak, sehingga ketersediaan jajanan di sekolah perlu mempertimbangkan determinan pemilihan jajanan anak serta kontribusi gizi jajanan. Kata kunci : Kontribusi gizi, pemilihan jajanan, status gizi
\end{abstract}

\section{ABSTRACT}

Fulfilment children's nutritional needs is important to support growth and development. The dietary habit of school-age children which tends to prefer snacks at school rather than eating at homewill affect the nutritional status of children. The purpose of this study was to analyze determinant factors of snacks choice, relationship between snacks choice with frequency of snacks, and relationship of nutrition contribution of snacks with nutritional status of children. This study was a cross-sectional study funded by the Neys-van Hoogstraten Foundation, the Netherlands and was conducted at three primary schools namely SDN Kedokan, SDN Pajajaran and SDN Cibogo in Cisauk Sub-District, Tangerang Regency with total subjects of this study were 109 students. Factor-analysisand Rank Spearman relationship tests were used to analyze data. There are five main factors that determine thesnacks choice, namely familiarity factor, characteristics of snacks, environmental and social, nutritional content and variation, and health. Health factors and snack characteristics had significant relationships with frequency of snacks $(p<0.05)$. The contribution of energy, protein, fat and carbohydrate had significant relationships with the nutritional status of children $(p<0.05)$. The study resultshows that snack choice played an important role in snacking habits and nutrition contribution of snacks had an impact on nutritional status of children, therefore availability of snacks at school should consider the children's snack choice and nutritioncontribution of snacks.

Keywords: Nutrition contributions, nutritional status, snacks choice 


\section{PENDAHULUAN}

Masa anak-anak merupakan masa pertumbuhan dan perkembangan. Anak-anak perlu mendapatkan zat gizi sesuai dengan kebutuhan untuk mendukung pertumbuhan dan perkembangan yang optimal. Pola makan dan nafsu makan anak-anak mengalami perubahan ketika memasuki usia sekolah pada usia 6 sampai 12 tahun. Anak sudah mulai menentukan sendiri makanan yang akan mereka makan di sekolah. Anak cenderung lebih memilih jajan dan makan di luar rumah dibandingkan makan di rumah. Hal ini menyebabkan kontribusi asupan zat gizi dari jajanan cenderung meningkat. ${ }^{1,2}$

Di Indonesia, makanan jajanan merupakan bagian yang tidak dapat terpisahkan dengan anak sekolah. Kebiasaan jajan anak dapat dilihat dari frekuensi jajan dan kontribusi gizi jajanan. Hasil penelitian Mudiani et al., tahun 2018 menunjukkan kontribusi energi jajanan tertinggi adalah 607 kkal dan sebanyak 19\% anak-anak tergolong lebih untuk kontribusi jajannya. ${ }^{3}$ Penelitian lain menunjukkan hal yang serupa dimana kontribusi energi jajanan cukup besar yaitu sebesar $24.7 \%$ terhadap asupan harian atau $494 \mathrm{kkal} .{ }^{4}$ Disisi lain, terdapat permasalahan keamanan pangan jajanan. Ketersediaan jajanan belum terjamin keamanan pangannya. Jajanan yang tidak aman ditandai dengan adanya bakteri, senyawa kimia berbahaya, serta virus yang menyebabkan diare sampai kanker. ${ }^{5}$ Hasil survei jajanan di wilayah pedesaan Kabupaten Tangerang menunjukkan jajanan yang tidak memenuhi syarat dikarenakan penggunaan pemanis yang berlebihan. Selain itu, kecamatan Cisauk di Kabupaten Tangerang memiliki tempat pengelolaan makanan jajajan yang tidak memenuhi hygiene dan santasi dengan jumlah tertinggi. ${ }^{6}$

Pemilihan jajanan merupakan bagian penentu kebiasaaan jajan. Anak-anak memiliki berbagai pertimbangan dalam menentukan jajanan yang mereka pilih dan konsumsi. Penelitian Kristianto et al., tahun 2013 harga, porsi, aroma, pengaruh teman dan rasa merupakan faktorfaktor yang menentukan pemilihan jajanan anak sekolah dasar Kota Batu. ${ }^{7}$ Penelitian Iklima, tahun 2017 menunjukkan bahwa rasa, harga, merk, ketersediaan jajanan dan tekstur dapat menjadi indikator pemilihan jajan pada anak sekolah dasar.
Jajanan yang paling sering dikonsumsi adalah minuman berperisa dan cireng. ${ }^{8}$ Perlu diketahui faktor-faktor yang mempengaruhi pemilihan jajanan karena faktor tersebut akan menentukan jajanan yang dipilih dan konsumsi serta seberapa sering anak jajan.

Kebiasaan jajan dapat meningkatkan asupan energi yang melebihi energi yang dikeluarkan. Konsumsi jajanan dalam porsi yang besar maka akan menyumbangkan asupan energi yang tinggi dan dapat mengakibatkan kelebihan asupan energi sehingga memicu adanya penambahan berat badan. ${ }^{9}$ Berdasarkan data Riset Kesehatan Dasar Banten tahun 2013 prevalensi gizi kurang menurut IMT/U pada anak umur 5-12 tahun di Kabupaten Tanggerang merupakan prevelensi tertinggi di provinsi Banten yaitu13.2\%. Prevalensi gizi lebih juga di Kabupaten Tangerang sebesar $20.3 \%$ yang melebihi prevalensi nasional. ${ }^{10}$

BPOM telah melakukan gerakan aksi nasional Pangan Jajanan Anak Sekolah (PJAS) untuk meningkatkan keamanan dan mutu jajanan anak sekolah. Mengingat besarnya kontribusi jajanan anak sekolah, keamanan pangan jajanan yang belum memadai di Kabupaten Tangerang, prevelensi gizi lebih di Kabupaten Tangerang melebihi prevalensi nasional, serta perlunya data untuk mendukung program pemerintah, maka perlu dilakukan penelitian untuk mengumpulkan data mengenai keterbaruan kebiasaan jajan anak sekolah, dan bagaimana dampaknya pada status gizi anak. Data faktor-faktor yang mempengaruhi pemilihan jajan anak juga penting diketahui untuk dapat digunakan sebagai dasar strategi penyediaan dan pengelolaan jajanan aman dan bermutu. Jajanan yang bergizi dan aman merupakan kunci untuk mendukung kehidupan dan kesehatan yang baik. Oleh karena itu, penelitian ini bertujuan untuk: 1) mengidentifikasi faktor-faktor yang mempengaruhi pemilihan jajan 2) Hubungan pemilihan jajan dengan frekuensi jajan serta hubungan kontribusi jajan dengan status gizi anak sekolah di Kabupaten Tangerang Provinsi Banten.

\section{BAHAN DAN METODE}

Desain penelitian yang digunakan adalah metode cross-sectional. Penelitian ini dilakukan 
di Kecamatan Cisauk Kabupaten Tangerang yang terdiri dari tiga SD yaitu SDN Kedokan, SD Pajajaran dan SDN Cibogo. Pemilihan lokasi penelitian dilakukan secara purposive (sengaja) karena beberapa pertimbangan. Pertimbangan tersebut diantaranya hasil survei PJAS di wilayah pedesaan Kabupaten Tangerang menunjukkan beberapa PJAS yang tidak memenuhi syarat keamanan pangan, yaitu menggunakan pemanis yang berlebihan. Selain itu, kecamatan Cisauk di Kabupaten Tanggerang memiliki tempat pengelolaan makanan jajajan yang tidak memenuhi hygiene dan santasi dengan jumlah tertinggi. Prevalensi masalah gizi kurang dan gizi lebih di Kabupaten Tangerang cukup tinggi. Penelitian ini dilaksanakan pada bulan Agustus-September 2018. Penelitian ini merupakan bagian dari penelitian yang berjudul Children Food Consumption, Snacking Habits and Food Safety Analysis in School Environment yang didanai oleh Neys-van Hoogstra ten Foundation. Perhitungan sampel menggunakan rumus estimasi rata-rata pada satu populasi ${ }^{11}$. Perhitungan sampel sebagai berikut :

$$
\begin{aligned}
& n=\frac{z_{1-\alpha / 2^{2}}\left(2 \sigma^{2}\right)}{d^{2}} \\
& n=\frac{1.96^{2}\left(2 \times 0.186^{2}\right)}{0.05} \\
& n=106.3 \sim 107
\end{aligned}
$$

Keterangan :

$\mathrm{n} \quad=$ Besar sampel

$\mathrm{Z}_{1-\alpha / 2}=$ Derajat kepercayaan 95\% (1.96)

$\sigma=$ Standar deviasi kontribusi jajan terhadap asupan $(18.6 \%=0.186)^{11}$

$\mathrm{d} \quad=5 \%=0.05$

Kriteria inklusi yang ditetapkan untuk pengumpulan sampel merupakan siswa-siswi kelas 5, dapat berkomunikasi dengan baik, dan bersedia menjadi contoh penelitian. Kriteria ekslusinya adalah sakit dan tidak bersedia mengikuti penelitian. Sampel minimal yang dibutuhkan adalah 107. Cara pengambilan sampel ini adalah mengambil seluruh siswa kelas 5 yang ada di ketiga sekolah yang telah memenuhi kriteria inklusi. Sampel yang terkumpul berjumlah 109 siswa dan sudah memenuhi syarat minimal sampel.
Jenis data yang terkumpul meliputi jenis kelamin, usia, uang saku, faktor-faktor yang pemilihan jajanan dan kebiasaan jajan (frekuensi jajan per hari dan kontribusi energi, protein, lemak dan karbohidrat dari jajanan), konsumsi makanan 24 jam selama dua hari, serta antropometri siswa (berat badan dan tinggi badan). Data subjek diperoleh melalui wawancara dengan anak menggunakan kuesioner. Data pemilihan jajanan diperoleh dengan menggunakan kuesioner dengan penyesuaian skala likert menjadi 3 pilihan karena responden pada penelitian ini adalah siswa sekolah dasar. Kuesioner yang digunakan sudah diuji validitas dan reabilitas. Pertanyaan terdiri dari 20 pertanyaan mengenai alasan pemilihan jajajan. Salah satu contoh pertanyaan mengenai alasan porsi yang banyak adalah Bagaimana pendapat adik jika jajanan yang adik beli harus memiliki porsi yang besar? Jawabannya adalah setuju, biasa saja atau tidak setuju. Data konsumsi pangan contoh diperoleh menggunakan kuesioner food recall 24 jam selama 2 kali. Data asupan jajanan siswa diperoleh dengan memisahkan antara konsumsi pangan harian siswa dengan jajanan contoh yang terdapat dalam kuesioner food recall 24 jam selama dua kali. Data antropometri yaitu berat badan dan tinggi badan diperoleh melalui pengukuran secara langsung. Berat badan diukur dengan timbangan sedangkan tinggi badan diukur dengan menggunakan staturemeter. Proses pengolahan meliputi kegiatan editing, coding, entry, dan cleaning. Pengolahan data dilakukan dengan menggunakan Microsoft Excel 2016 dan dianalisis dengan menggunakan program SPSS version 16.0 for Windows. Status gizi pada anak diukur menggunakan WHO Antro Plus. Kriteria

Tabel 1. Gambaran Karakteristik Siswa

\begin{tabular}{lc}
\hline \multicolumn{1}{c}{ Variabel } & $\mathbf{n}(\%)$ \\
\hline Usia (tahun) & \\
$<10$ & $23(21.1)$ \\
$10-11$ & $69(64.3)$ \\
$>11$ & $15(14.7)$ \\
$\quad$ Rata-rata \pm SD & $10.4 \pm 0.7$ \\
Uang saku (Rp) & \\
5000 & $26(23.9)$ \\
$>5000-10000$ & $85(59.6)$ \\
$>10000$ & $18(16.5)$ \\
Rata-rata \pm SD & $8963 \pm 3761$ \\
$\quad$ Minimal; Maksimal & $2000 ; 20000$ \\
\hline
\end{tabular}


Tabel 2. Faktor-Faktor yang Mempengaruhi Pemilihan Jajan Siswa

\begin{tabular}{llcc}
\hline \multicolumn{1}{c}{ Faktor } & \multicolumn{1}{c}{ Alasan pemilihan jajanan } & Korelasi & \% Varians \\
\hline Familiaritas & Jajanan yang iklannya sering muncul di TV & 0.820 & 22.230 \\
& Jajanan terkenal & 0.725 & 0.675 \\
& Jajanan yang dibeli teman & & 10.219 \\
Karakteristik Jajanan & Teksturnya empuk dan menarik & 0.678 & 0.657 \\
& Jajanan yang porsinya besar & 0.539 & 9.402 \\
& Harga yang murah dan enak & 0.531 & \\
Lingkungan dan sosial & Iklan yang menarik dan ada hadiahnya & 0.519 & 0.729 \\
& Jajanan yang dianjurkan oleh orang tua & 0.747 & \\
Kandungan gizi dan & Jajanan yang mudah tersedia diwarung & 0.799 & 6.769 \\
variasi & Jajanan teman untuk jajan & 0.656 & \\
Kesehatan & Jajanan yang banyak jenisnya & 0.692 & \\
\hline
\end{tabular}

pengelompokan status gizi berdasarkan WHO tahun 2007 yaitu dikatakan sangat kurus jika nilai SD-nya $<-3 \mathrm{SD}$, kurus jika $\geq 3$ SD s/d $-2 \mathrm{SD}$, normal jika -2.0 SD s/d 1.0 SD dan gemuk jika $>1$ SD. ${ }^{13}$ Analisis univariat dilakukan secara deskriptif untuk menggambarkan sebaran usia, jenis kelamin, uang saku, frekuensi jajan, dan kontribusi jajan yang berdasarkan persen, rataan dan standar deviasi. Analisis faktor dilakukan untuk mengetahui faktor-faktor determinan pemilihan jajan. Data kontribusi jajan diperoleh dengan membandingkan asupan jajan dengan asupan total sehari. Data asupan jajanan dan asupan sehari diperoleh dari perhitungan konsumsi makanan yang dikonversi menjadi nilai kandungan gizi, yaitu energi, protein, lemak dan karbohidrat berdasarkan Daftar Komposisi Bahan Makanan menggunakan program Microsoft Excel 2007. Analsis bivariat dengan uji korelasi Rank Spearman dilakukan untuk melihat hubungan pemilihan jajan dengan frekuensi jajan dan kontribusi gizi jajanan dengan status gizi. Penelitian ini telah mendapat persetujuan etik yang berasal dari Komisi Bioetika Penelitian Kedokteran/Kesehatan Fakultas Kedokteran Universitas Islam Sultan Agung Semarang berupa Keterangan Lolos Kaji Etik (Ethical Approval) dengan Nomor : 207/IV/ETICS/2018 Komisi Bioetik tanggal 26 April 2018.

\section{HASIL}

Subjek dalam penelitian ini adalah siswa kelas 5 SD yang terdiri dari 55 orang laki-laki $(50.5 \%)$ dan 54 orang perempuan $(49.5 \%)$. Ratarata usia siswa adalah 10.4 dengan standar deviasi sebesar 0.7 . Siswa yang berusia kurang dari 10 tahun berjumlah 23 orang, $(21.1 \%)$ yang berusia 10 11 tahun 69 orang $(64.3 \%)$ dan yang berusia lebih dari 11 tahun berjumlah 15 orang (14.7). Rata-rata uang saku siswa sebesar Rp 8.963. Nominal uang saku terendah adalah 2,000 dan tertinggi adalah 20.000. Uang saku dalam penelitian ini merupakan jumlah uang yang dikeluarkan oleh siswa untuk membeli pangan dalam satu hari (Tabel 1).

Hasil analisis faktor dari 20 alasan pemilihan jajanan membentuk 5 faktor utama yang dapat diandalkan dan terdiri dari 13 alasan. Alasan yang dapat diandalkan jika memiliki nilai korelasi $>0.5$. Faktor pertama, yaitu variabel familiaritas yang terdiri dari alasan jajanan yang iklannya sering muncul di TV, jajanan terkenal dan jajanan yang biasa dibeli oleh teman. Faktor kedua, yaitu terkait karakteristik jajanan itu seperti warna yang menarik, tekstur yang empuk, porsi yang cukup banyak, rasa yang enak dan murah serta jajanan yang disertai hadiah yang menarik. Faktor ketiga, yaitu terkait pengaruh lingkungan dan sosial seperti anjuran orang tua, lokasi dari warung yang menjual jajan dan pengaruh ajakan teman. Faktor keempat, yaitu terkait kandungan gizi dan keraga- 
Tabel 3. Frekuensi Jajan dan Status Gizi Siswa

\begin{tabular}{cc}
\hline \multicolumn{1}{c}{ Variabel } & $\mathbf{n}(\%)$ \\
\hline Frekuensi jajan & \\
1 kali/hari & $14(12.8)$ \\
$2-3 \mathrm{kali} /$ hari & $86(78.9)$ \\
$\geq 4 \mathrm{kali} / \mathrm{hari}$ & $9(8.3)$ \\
Status gizi & \\
Gemuk & $14(23.9)$ \\
Normal & $74(67.9)$ \\
Kurus & $7(6.4)$ \\
Sangat kurus & $2(1.8)$ \\
\hline
\end{tabular}

man makanan seperti jenis jajanan dan kandungan gizi vitamin dan mineral. Faktor kelima, yaitu terkait manfaat kesehatan seperti makanan yang menyehatkan. Faktor familiaritas memiliki nilai \% variance tertinggi. Hal ini menunjukkan bahwa faktor tersebut merupakan faktor yang paling dominan dalam mempengaruhi pemilihan jajanan (Tabel 2).

Kebiasaan jajan siswa terdiri dari frekuensi jajan dan kontribusi jajan. Sebagian besar siswa yaitu 86 siswa (78.9\%) memiliki frekuensi jajan 2-3 kali/hari. Siswa lainnya sebanyak 13 orang (11.9\%) jajan sebanyak $1 \mathrm{kali} / \mathrm{hari}$ dan 10 siswa lainnya (9.2\%) jajan lebih dari 4 kali/hari (Tabel 3). Rata-rata asupan gizi jajanan siswa adalah $637 \pm 325$ kkal energi, $13 \pm 8.4$ gram protein, 215.7 kkal energi dari lemak dan 361 kkal energi dari karbohidrat. Rata-rata asupan gizi tersebut berkontribusi terhadap asupan harian. Kontribusi asupan energi sebesar $42.8 \pm 17.8 \%$, protein sebesar $31.9 \pm 18.8 \%$, energi dari lemak $14.2 \%$ dan energi dari karbohidrat sebesar $24.6 \pm 9.9 \%$ terhadap asupan harian (Tabel 4). Status gizi siswa dikelompokkan menjadi 5 kelompok yaitu sangat kurus, kurus, normal, gemuk dan obesitas. Sebagian besar subjek $(67.9 \%)$ memiliki status gizi normal. Siswa yang memiliki status gizi gemuk (23.8\%) lebih banyak dibandingkan siswa yang memiliki status gizi kurus (6.4\%) dan sangat kurus (1.8\%) (Tabel 3).

Hasil uji hubungan Rank Spearman menunjukkan terdapat 2 faktor dari pemilihan jajan yang berhubungan dengan frekuensi jajan. Faktor kesehatan dengan alasan jajanan yang bergizi dan menyehatkan berhubungan dengan frekuensi jajan $(\mathrm{p}=0.022 ; \mathrm{r}=0.220)$ dan variabel karakteristik jajanan dengan alasan teksturnya empuk dan

\begin{tabular}{lc}
$\begin{array}{l}\text { Tabel 4. Asupan dan Kontribusi Gizi Jajanan } \\
\text { pada Siswa }\end{array}$ \\
\hline \multicolumn{1}{c}{ Zat Gizi } & Total \\
\hline Energi (kkal) & $637 \pm 325$ \\
Kontribusi terhadap asupan harian (\%) & $42.8 \pm 17.8$ \\
Protein (g) & $13 \pm 8.4$ \\
Kontribusi terhadap asupan harian (\%) & $31.9 \pm 18.8$ \\
Energi dari lemak (kkal) & $215.7 \pm 138.0$ \\
Kontribusi terhadap asupan harian (\%) & $14.2 \pm 7.4$ \\
Energi dari Karbohidrat (kkal) & $361.3 \pm 177.8$ \\
Kontribusi terhadap asupan harian (\%) & $24.6 \pm 9.9$ \\
\hline
\end{tabular}

menarik berhubungan dengan frekuensi jajan $(p=0.032 ; r=0.205)$ (Tabel 5). Status gizi berhubungan positif dengan kontribusi jajan energi $(\mathrm{p}=0.006 ; \mathrm{r}=0.259)$, protein $(\mathrm{p}=0.010 ; \mathrm{r}=0.247)$, lemak $(\mathrm{p}=0.007 ; \quad \mathrm{r}=0.257)$, dan karbohidrat jajanan $(\mathrm{p}=0.042 ; \mathrm{r}=0.195)$ (Tabel 6). Persentase kontribusi energi berbanding lurus dengan tingkatan status gizi. Siswa yang terkategori sangat kurus, kurus, normal, gemuk, memiliki ratarata kontribusi energi sebesar $28.75 \%, 35.17 \%$, $40.96 \%, 51.01 \%, 48.17 \%$, kontribusi protein $22.90 \%, 23.96 \%, 29.65 \%, 40.92 \%$, kontibusi lemak $7.6 \%, 10.96 \%, 13.50 \%, 17.04 \%$ serta kontribusi karbohidrat $19.40 \%, 21.96 \%, 23.52 \%$, dan 28.68 secara berturut-turut (Tabel 6).

\section{PEMBAHASAN}

Familiaritas terhadap makanan merupakan suatu ungkapan yang menunjukkan seseorang sudah sangat mengenal makanan tersebut. Hasil analisis faktor terkait familiaritas menunjukkan faktor yang dominan pada pemilihan jajan anak. Penelitian ini menunjukkan jajanan-jajanan yang sudah sangat siswa kenal menjadi faktor penentu siswa dalam memilih jajanan. Anak-anak cenderung akan memilih makan yang sudah sangat dikenal untuk dikonsumsi. Anak sering menonton TV kemudian tertarik pada iklan yang sering muncul dan ingin mencobanya. Anak-anak menghabiskan waktu lebih banyak untuk menonton TV dibandingkan dengan keluarga. Hal ini memberikan perubahan pada perilaku anak. Anak-anak cenderung menginginkan makanan yang iklannya menarik. Dampak positifnya adalah beberapa media dapat memberikan informasi makananmakanan yang bergizi untuk anak-anak. Disisi lain, terdapat juga iklan-iklan yang masih mem- 
Tabel 5. Hubungan Determinan Pemilihan Jajanan dengan Frekuensi Jajan

\begin{tabular}{clcc}
\hline \multirow{2}{*}{ Faktor } & \multicolumn{1}{c}{ Alasan pemilihan jajanan } & Frekuensi Jajan \\
\cline { 2 - 3 } & & r & p \\
\hline Familiaritas & Jajanan yang iklannya sering muncul di TV & 0.125 & 0.197 \\
& Jajanan terkenal & 0.093 & 0.336 \\
& Jajanan yang dibeli teman & 0.110 & 0.255 \\
Karakteristik Jajanan & Teksturnya empuk dan menarik & 0.205 & 0.032 \\
& Jajanan yang porsinya besar & 0.146 & 0.129 \\
& Harga yang murah dan enak & 0.077 & 0.426 \\
& Iklan yang menarik dan ada hadiahnya & 0.137 & 0.155 \\
Lingkungan dan sosial & Jajanan yang dianjurkan oleh orang tua & -0.039 & 0.684 \\
& Jajanan yang mudah tersedia diwarung & 0.044 & 0.651 \\
& Ajakan teman untuk jajan & 0.067 & 0.486 \\
Kandungan gizi dan & Jajanan mengandung vitamin dan mineral & -0.174 & 0.070 \\
variasi & Jajanan yang banyak jenisnya & -0.090 & 0.354 \\
Kesehatan & Bergizi dan menyehatkan & & 0.220 \\
\hline
\end{tabular}

Tabel 6. Hubungan Kontribusi Gizi Jajanan dengan Status Gizi Siswa

\begin{tabular}{lcccccc}
\hline \multirow{2}{*}{ Variabel } & \multicolumn{3}{c}{ Kategori Status Gizi } & \multirow{2}{*}{ p } & \\
\cline { 2 - 5 } & Sangat Kurus & Kurus & Normal & Gemuk & & 0.006 \\
Persentase kontribusi energi (\%) & 28.75 & 35.17 & 40.96 & 51.01 & \\
Persentase kontribusi protein (\%) & 22.90 & 23.96 & 29.65 & 40.92 & 0.010 \\
Persentase kontribusi lemak (\%) & 7.60 & 10.94 & 13.50 & 17.48 & 0.007 \\
Persentase kontribusi karbohidrat (\%) & 19.40 & 21.96 & 23.52 & 28.68 & 0.042 \\
\hline
\end{tabular}

promosikan jajanan yang tinggi gula, lemak dan garam yang akan memengaruhi asupan yang berlebih pada anak-anak. Pengaruh teman sebaya meningkat seiring bertambahnya usia dan memengaruhi sikap dan pemilihan makanan. Anakanak cenderung memilih makanan berdasarkan pilihan makanan temannya atau mengikuti makanan yang dipilih temannya. Ketika berada di sekolah, anak-anak mudah terpengaruh oleh temannya. Pemilihan makanan pada anak dirumah cenderung berdasarkan makanan yang dimakan temannya disekolah. Anak-anak antusias mencoba makanan yang baru yang dimakan oleh temannya. ${ }^{1,14}$ Faktor karaktertistik jajanan yang menjadi faktor determinan pemilihan jajan anak didukung dengan teori Contento mengenai determinan food choice yang menyatakan bahwa sebagian orang akan memilih makanan berdasarkan tekstur dan rasa makanan. Respons sensoris-afektif terhadap penglihatan, pengecapan dan tekstur makanan merupakan pengaruh utama pada preferensi makanan dan pilihan makanan. ${ }^{15}$

Karakteristik jajanan yang memiliki porsi makan yang besar akan menjadi pertimbangan bagi anak-anak dalam memilih makanan untuk dikonsumsi. Anak-anak cenderung memilih makanan yang mengenyangkan seperti makanan sepinggan nasi uduk dan mie. Penelitian serupa menunjukkan porsi yang besar menjadi daya tarik bagi anak untuk membeli karena membuat kenyang dan memberikan asupan zat gizi yang lebih. ${ }^{7}$ Harga juga menentukan pemilihan pangan dan pola makan. Harga yang murah dan enak menjadi dasar pertimbangan jajan anak karena semakin murah harga jajanan anak-anak dapat membeli jajanan yang lebih banyak jenisnya. Jajajan anakanak berkisar 500-3000. Semakin murah jajanan anak akan semakin dapat membeli banyak jajanan. Jajanan yang murah seperti gorengan, telur gulung dan cilor. Buah cenderung lebih mahal sehingga 
jarang dibeli orang siswa. Penelitian Febrianto, tahun 2016 menunjukkan seorang pembeli makanan cenderung memilih makanan yang harganya murah walaupun mutu dan kualitasnya rendah. ${ }^{16}$

Hubungan sosial yang terjalin antara seseorang dengan keluarga atau teman seperti bercerita atau pemberian saran akan menentukan makanan yang dipilih. ${ }^{15}$ Anak-anak cenderung mempertimbangkan anjuran orang tua dan ajakan teman dalam memilih jajan. Penelitian Aulia dan Yuliati, tahun 2018 mendukung hasil penelitian ini yang menunjukkan bahwa faktor orang tua dan teman mempengaruhi seseorang dalam pemilihan jajanan. Faktor orang tua yang berpengaruh yaitu dari pola asuh terhadap anak sedangkan faktor teman adalah paparan informasi. ${ }^{17}$ Bimbingan orang tua juga diperlukan agar anak dapat memilih makanan yang sehat ketika anak membeli makan di luar rumah. Anak cenderung memilih makanan yang dianjurkan orang tua. Hal ini berkaitan dengan kemampuan orang tua dalam meyakinkan anak untuk mengikuti anjuran orang tua dalam memilih jajanan. Penelitian Faught et al., tahun 2015 menunjukkan sebagian besar orang tua peduli terhadap asupan anak dan memberikan anjuran kepada anak untuk makan makanan yang sehat. Anak-anak dari orang tua yang peduli terhadap asupan anak memiliki kualitas asupan yang lebih tinggi dibandingkan dengan anak-anak dari orang tua kurang peduli terhadap asupan anak anak. ${ }^{18}$ Faktor lingkungan dicerminkan dari segi ketersediaan dan aksesibilitas makanan. ${ }^{15}$ Anakanak lebih nyaman dengan lingkungan yang dekat karena aksesnya mudah dan menghemat waktu sehingga mereka memilih jajanan yang sudah tersedia diwarung terdekat. Hal ini mungkin juga dikarenakan waktu anak yang terbatas ketika istirahat sekolah. Penelitian serupa menunjukkan waktu menjadi pertimbangan anak dalam memilih jajan. Anak-anak cenderung memilih makanan yang cepat saji dan warung yang terdekat ketika mereka memiliki waktu yang terbatas. ${ }^{19}$

Faktor kandungan gizi dan variasi makanan sudah dipertimbangkan oleh anak-anak. Ketersediaan jajan berhubungan dengan konsumsi jajanan anak cenderung memilih jajanan dan mengonsumsi jajanan yang bervariasi karena ketersediaan jajan yang bervariasi. Penelitian lain oleh
Ansem et al., tahun 2015 membuktikan bahwa ketersediaan jajanan akan mempengaruhi konsumsi anak. ${ }^{20}$ Penelitian Ayuniyah et al., tahun 2015 juga menunjukkan bahwa ketersediaan jajanan memiliki pengaruh terhadap konsumsi jajan. Semakin banyak tersedia jajanan maka anak mudah mengaksesnya dan meningkat konsumsi jajanannya. ${ }^{21}$ Aspek manfaat kesehatan sudah dipertimbangkan anak-anak dalam pemilihan jajanan. Hal ini dimungkinkan anak mengikuti anjuran orang untuk memilih jajanan yang sehat. Penelitian Rahmi, menunjukkan bahwa ibu yang berpengetahuan baik akan memberikan arahan kepada anaknya untuk memilih jajajan yang sehat. ${ }^{22}$

Frekuensi jajan adalah berapa kali jajan dalam sehari. Penelitian terkait frekuensi jajan menghasilkan data yang bervariasi. Hasil penelitian ini sebagian besar frekuensi jajan siswa tergolong sering karena anak-anak biasa melakukan jajan sebelum masuk sekolah, ketika istirahat, pulang sekolah dan ketika di rumah. Penelitian Merhamah et al., tahun 2014 menunjukkan frekuensi jajan anak sekolah rata-rata 3 kali/hari. ${ }^{23}$ Selain itu, dukungan uang saku yang tinggi dapat meningkatkan frekuensi jajan anak. Penelitian Murni et al., tahun 2016 menunjukkan frekuensi jajan yang tinggi dapat dikarenakan pemberian uang saku yang besar oleh orang tua yang berpenghasilan tinggi. ${ }^{24}$ Perilaku jajan pada siswa dapat diibaratkan selingan. Rata-rata kontribusi zat gizi dari jajanan siswa (42.8\%) melebihi anjuran selingan. Badan Ketahanan Pangan tahun 2018 menganjurkan kontribusi energi dan protein selingan sebesar $20 \% .{ }^{25}$ Pada peneltian ini tingginya kontribusi energi jajanan mungkin dikarenakan orang tua yang tidak memasak makanan sehingga anak diberikan uang saku lebih untuk jajan. Terdapat penelitian-penelitian lain yang menunjukkan kontribusi jajanan melebihi anjuran selingan. Penelitian Shriver et al., tahun 2017 menunjukkan kontribusi energi jajanan sebesar $28.0 \%$ dan kontribusi energinya sebesar $32 \% .{ }^{26}$ Penelitian serupa lainnya menunjukkan jajanan mengkontribusikan energi sebesar $30 \%$. Tingginya kontribusi jajanan dapat dikarenakan anak tidak sarapan sehingga mereka menggantikan sarapan dengan jajanan. Namun, kualitas jajanan belum baik karena jajanan umumnya 
tinggi energi, lemak namun rendah protein. ${ }^{12}$ Disisi lain, terdapat penelitian yang menyatakan bahwa kontribusi jajanan tidak melebihi anjuran. Penelitian hari kedua, tahun 2015 menyebutkan bahwa kontribusi jajanan pada anak usia 9 tahun adalah $8-15 \%$. Kontribusi jajanan yang berbeda-beda pada setiap penelitian dapat dikarenakan ketersediaan jajanan yang berbeda-beda dan pengetahuan gizi yang kurang. ${ }^{27}$ Status gizi gemuk pada anak sekolah lebih tinggi dibandingkan presentase anak yang memiliki status gizi yang kurus. Hal ini selaras dengan penelitian Rahmawati dan Marfuah, tahun 2016 status gizi gemuk anak sekolah dasar lebih tinggi dibandingkan anak dengan status gizi kurus. Salah satu faktor penyebab terjadinya obesitas pada anak karena konsumsi asupan yang berlebih yang bersumber dari jajanan. ${ }^{28}$ Hal ini bertolak belakang dengan penelitan Seprianty et al., 2016 yang menunjukkan status gizi gemuk anak sekolah lebih rendah karena pendapat orang tua pada penelitian tersebut didominasi kurang dari 3 juta rupiah. ${ }^{29}$

Hubungan positif yang terjadi pada faktor kesehatan sebagai determinan jajanan dengan frekuensi jajan menunjukkan semakin siswa yang mempertimbangkan faktor kesehatan yaitu jajanan yang sehat dan bergizi akan semakin sering jajan. Pengetahuan anak mengenai jajan yang sehat akan mendukung anak lebih sering jajan jajanan yang sehat. Variabel karakteristik jajanan dengan alasan jajanan yang menarik dan teksturnya empuk berhubungan dengan frekuensi jajan. Anak akan semakin sering jajan jika jajanan tersebut menarik. Hal ini dapat dikaitkan dengan kenyamanan anak dalam mengonsumsi jajanan. Anak cenderung mengonsumsi jajanan yang nyaman bagi dirinya. Tekstur yang empuk dimungkinkan memberikan kenyamanan anak dalam mengonsumsi jajanan sehingga ketika sudah nyaman akan berdampak seringnya mengonsumsi jajanan tersebut. Penelitian Jannah et al., tahun 2017 menunjukkan frekuensi jajanan pisang goreng lebih tinggi dibandingkan cemilan kering seperti keripik. Hal ini menunjukkan makanan dengan tekstur yang empuk pada pisang goreng lebih sering dikonsumsi oleh anak sekolah dibandingkan keripik yang teksturnya keras. ${ }^{26}$

Penelitian ini menunjukkan hubungan yang nyata antara status gizi dan kontribusi jajan (energi, protein, lemak dan karbohidrat). Anak yang gemuk dan obesitas cenderung lebih tinggi kontribusi jajannnya dibandingkan anak yang kurus. Sebagian besar jajanan yang ada di sekolah diolah secara digoreng. Hal ini dapat menyebabkan sumbangan yang tinggi pada energi dan lemak. Terdapat beberapa penelitian serupa yang menyatakan adanya hubungan kebiasaan jajan dengan status gizi. Penelitian Hanrizon, tahun 2016 menyatakan sebagian besar anak dengan status gizi gemuk lebih sering mengonsumsi makanan jajanan dibandingkan dengan anak yang status gizinya normal. Anak dengan status gizi normal lebih menyukai jajanan seperti kue, biskuit, minuman kemasan dan soda, sedangkan anak dengan status gizi gemuk lebih menyukai jenis jajanan seperti gorengan, minuman kemasan, dan fastfood. ${ }^{30}$ Penelitian lain menunjukkan hasil yang serupa dimana anak yang terbiasa jajan cenderung memiliki asupan energi yang tinggi dibandingkan dengan anak yang tidak terbiasa jajan. Kebiasaan mengonsumsi jajanan berhubungan dengan peningkatan asupan energi dan signifikan berpengaruh terhadap asupan zat gizi. ${ }^{31}$ Penelitian Noviani et al., tahun 2014 menunjukkan responden yang memiliki kebiasaan jajan sering dan status gizi normal sebanyak 27 responden dan yang tidak sering jajan dengan status gizi kurus berjumlah 7 responden. ${ }^{32}$ Hasil penelitian Sulchan dan Pramono, tahun 2014 juga menyatakan kontribusi gizi jajanan yang tinggi $>300 \mathrm{kkal}$ berisiko sebesar 3.2 kali menyebabkan obesitas. ${ }^{33}$

\section{KESIMPULAN DAN SARAN}

Penelitian ini menyimpulkan bahwa frekuensi jajan anak tergolong sering dan rata-rata kontribusi zat gizi jajanan terhadap asupan harian melebihi anjuran selingan yaitu $>20 \%$. Hal ini dapat dikarenakan ketersediaan jajanan yang tinggi energi dan lemak dan kebiasaan siswa yang lebih memilih jajan diluar karena orang tua tidak memasak dan kebiasaan melewatkan sarapan. Terdapat 5 faktor utama yang menjadi determinan pemilihan jajan berdasarkan alasannya. Variabel tersebut adalah familiaritas, karakteristik jajanan, lingkungan dan sosial, kandungan gizi dan variansi serta kesehatan. Faktor kesehatan dan karakteristik jajanan memiliki hubungan yang signifikan dengan frkekuensi jajan $(p<0.05)$. Kontribusi 
energi, protein, lemak dan karbohidrat berkorelasi positif dengan status gizi anak $(\mathrm{p}<0.05)$. Semakin tinggi kontribusi jajan anak maka status gizi anak akan semakin meningkat.

Hasil penelitian ini menunjukkan bahwa kontribusi jajanan terhadap asupan sehari cukup tinggi maka diharapkan adanya dukungan dari ketersediaan jajanan yang bergizi dan aman dikonsumsi. Penyediaan jajanan juga perlu mempertimbangkan faktor-faktor yang mempengaruhi anak dalam memilih jajanan. Selain bergizi dan aman, perlu penyediaan jajanan yang teksturnya empuk, jajanan yang menarik, harga yang murah dan jajanan yang banyak jenisnya sehingga anakanak cenderung akan memilih jajanan tersebut. Familiaritas menjadi faktor yang paling dominan mempengaruhi pemilihan jajanan anak, maka dianjurkan bagi pihak sekolah untuk mengingatkan anak-anak untuk memilih jajanan yang bergizi dan aman dan memberi tahu jenis jajanan-jajanan yang bergizi. Semakin sering guru memberikan arahan atau mengingatkan muridnya maka murid tersebut akan semakin ingat dan sangat mengenal jajanan yang dianjurkan.

\section{UCAPAN TERIMA KASIH}

Penulis mengucapkan terimakasih kepada Neys-van Hoogstraten Foundation, the Netherlands yang telah mendanai penelitian ini.

\section{DAFTAR PUSTAKA}

1. Mahan LK, Raymond JL. Krause's Food and the Nutrition Care Process. International 14th Edition. Canada: Saunders Elsevier; 2017.

2. Rosenkranz RR, Matalia R, Natalie U, Sara R, David AD. Behaviorally Oriented Nutrition Education at a Russian Summer Camp Improves Children's Dietary Choice: A Quasi-Experimental Study. BioMed Central. Nutrire. 2017;42(18):1-8.

3. Mudiani NPR, Nursanyato H, Gumala NMY. Status Gizi dan Kontribusi Konsumsi Makanan Jajajan Anak Sekolah di SD 2 Penatih Denpasar Timur. Jurnal Ilmu Gzi. 2018;7(1):26-28.

4. Murni SS, Syamsianah A, Mufnaetty. Perbedaan Asupan Energi Makanan Jajanan dan Status Obesitas berdasarkan Status Ekonomi Keluarga pada Siswa SDN Sambiroto 01 Kota Semarang. Jurnal Gizi. 2016;5(1):44-51.
5. Kementrian Kesehatan Republik Indonesia. Situasi Pangan Jajanan Anak Sekolah. Jakarta: Pusat Data dan Informasi Kementrian Kesehatan RI; 2015.

6. Dinas Kesehatan Kabupaten Tangerang. Profil Kesehaan Kabupaten Tangerang. Tangerang; Dinas Kesehatan Kabupaten Tangerang; 2016.

7. Kristianto $Y$, Bastianus DR, Annasari M. Faktor Determinan Pemilihan Makanan Jajanan pada Siswa Sekolah Dasar. Jurnal Kesehatan Masyarakat Nasional. 2013;7(11): 489-494.

8. Iklima N. Gambaran Pemilihan Makanan Jajajan Pada Anak Usia Sekolah Dasar. Jurnal Keperawatan BSI. 2017;5(1):8-17.

9. Sahoo K, Sahoo B, Choudhury AK, Sofi NY, Kumar R, Bhadoria AS. Childhood Obesity: Causes and Consequences. J Family Med Prim Care. 2015;4(2):187-92.

10. Kementerian Kesehatan Republik Indonesia. Riset Kesehatan Dasar Provinsi Banten. Jakarta : Badan Penelitian dan Pengembangan Kesehatan; 2013.

11. Lemeshow S, Jr DWH, Klar J, Lwanga SK. Adequacy of Sample Size in Health Studies. England: John Wiley;1990.

12. Jannah KK. Hubungan Kebiasaan Sarapan dan Kebiasaan Jajan dengan Status Gizi Siswa Sekolah Dasar di Kabupaten Sukabumi [Skripsi]. Bogor: Institut Pertanian Bogor; 2017.

13. World Health Organitation. Growth reference 5-19 years. [Online Web]. [Diakses 10 Agustus 2018]. Available at: http://www.who.int/ growthref/who2007/bmiforage/en/index.html.

14. Sharlin J, Sari E. Essentials of Life Cycle Nutrition. Canada: Jones Barlett Publisher; 2011.

15. Contento I. Nutrition Education: Linking Research, Theory, and Practice, Second Edition. Sudbury: Jones and Bartlett Publishers; 2011.

16. Febrianto MAB. Hubungan antara Pengetahuan dan Sikap dengan Perilaku konsumen Jajajan di MI Sulaimaniyah Jombang. Jurnal Keperawatan Muhammadiyah. 2016;1(2): 7-17.

17. Aulia L, Yuliati L N. Faktor Keliarga, Media, Teman dalam Pemilihan Makanan pada Mahasiswa PPKU IPB. Jurnal Ilmu Keluarga dan Konsumen. 2018; 11(1):37-41. 
18. Faught E, Ploeg KV, Chu YL, Storey K, Veugelers. The Influence of Parental Encouragement and Caring about Healthy Eating on Children's Diet Quality and Body Weights. Public Health Nutrition. 2015;19(5):822-829.

19. Holsten JE, Deatrick JA, Kumanyika S, Martin JP. Children's Food Choice Process in the Home Environment. A Qualitative Descriptive Study. Elsevier Appetite. 2012;59(1):64-73.

20. Ansem WJ, Schrijvers CT, Rodenburg G, Mheen D. Children's Snack Consumption: Roe of Parents, Peers and Child SnackPurchasing Behaviour. Results from the INPACT Study. European Journal of Public Health. 2015;25(6):1006-1011.

21. Ayuniyah Q Yaktiworo I, Kordiyana KR. Ketersediaan dan Perilaku Konsumsi Makanan Jajanan Olahan Siswa Sekolah Dasar di Bandar Lampung. Media Neliti. 2015;3(4):409418.

22. Rahmi S. Cara Memilih Makanan Jajanan Sehat dan Efek Negatif yang ditimbulkan Apabila Mengonsumsi Makanan Jajanan yang Tidak Sehat bagi Anak-Anak Sekolah Dasar. Prosiding Seminar Nasional Hasil Penelitian. 2018;1(1);260-265.

23. Marhamah, Abzeni, Juwita. Perilaku Konsumsi dan Status Gizi Anak Sekolah Dasar di Kota Serang. Jurnal Matematika, Sains, dan Teknologi. 2014;15(2):97-105.

24. Murni SS, Syamsianah A, Mufnaetty. Perbedaan Asupan Energi Makanan Jajanan dan Status Obesitas Berdasarkan Status Ekonomi Keluarga pada Siswa SDN Sambiroto 01 Kota Semarang. Jurnal Gizi. 2016;5(1):44-52.

25. Badan Ketahanan Pangan. 2018. Sosialisasi Panduan Lomba Cipta Menu Beragam, Bergizi Seimbang dan Aman Berbasis Sumber Daya Lokal Tahun 2018. [Di Akses 1 Januari
2010]. Available at http://dkpp.jabarprov. go.id/wp-content/uploads/2018/04/Bahan-Sosialisasi-LCM-2018.pptx.

26. Shriver LH, Marriage BJ, Bloch TD, Spees CK, Ramsyah SA, Watowicz RP, Taylor CA. Contribution of Snacks to Dietary Intakes of Young Children in the United States. Maternal \& Child Nutrition. 2017;14(1):1-9.

27. Harikedua VT, Legi NN, Sarullah MR. Kontribusi Makanan Jajanan terhadap Total Energi dan Status Gizi pada Anak Sekolah di SD Inpres Buku Kecamatan Belang. Jurnal GIZIDO. 2015;7(1):1-8.

28. Rahmawati T, Marfuah D. Gambaran Status Gizi pada Anak Sekolah Dasar. Profesi (Profesional Islam) : Media Publikasi Penelitian. 2016;14(1):72-75.

29. Seprianty V, Tjekyan RMS, Thafa MA. Status Gizi Anak Kelas III Sekolah Dasar Negeri 1 Sungaililin. Jurnal Kesehatan Publikasi lmiah Fakultas Kedokteran Universitas Sriwijaya. 2015;2(1):129-134.

30. Hanrizon M. Kebiasaan Jajan dan Kontribusinya terhadap Asupan Zat Gizi pada Siswa Sekolah Dasar di Bogor [Skripsi]. Bogor: Institut Pertanian Bogor; 2016.

31. Nuryani, Rahmawati. Kebiasaan Jajan Berhubungan dengan Status Gizi Siswa Anak Sekolah di Kabupaten Gorontalo. Jurnal Gizi Indonesia. 2018;6(2):114-122.

32. Noviani K, Afifah E, Astiti D. Kebiasaan Jajan dan Pola Makan serta Hubungannya dengan Status Gizi Anak Usia Sekolah Di SD Sonosewu Bantul. Jurnal Gizi dan Dietetik Indonesia. 2016;4(2):97-104.

33. Sulchan M, Pramono A. Kontribusi Makanan Jajan dan Aktivitas Fisik terhadap Kejadian Obesitas pada Remaja Di Kota Semarang.Gizi Indonesia. 2014;37(2):129-136. 